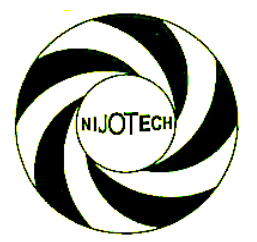

Nigerian Journal of Technology (NIJOTECH)

Vol. 38, No. 3, July 2019, pp. $\mathbf{5 4 9}$ - $\mathbf{5 5 6}$

Copyright@ Faculty of Engineering, University of Nigeria, Nsukka,

Print ISSN: 0331-8443, Electronic ISSN: 2467-8821

http://dx.doi.org/10.4314/njt.v38i3.2

\title{
SUITABILITY OF OLOKORO AND AMAOBA LATERITIC SOIL AS PAVEMENT CONSTRUCTION MATERIALS
}

\author{
H. K. Ugwuanyi ${ }^{1, *}$ and K. C. Onyelowe ${ }^{2}$

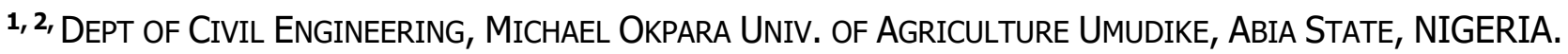 \\ E-mail addresses; ${ }^{1}$ henrykene9@gmail.com, ${ }^{2}$ konyelowe@mouau.edu.ng
}

\begin{abstract}
The suitability of Olokoro and Amaoba lateritic soils as pavement construction materials was investigated. Soil samples were collected from the borrow sites and were subjected to preliminary tests (natural moisture content, specific gravity, particle size analysis and Atterberg limits) and strength tests (compaction and California Bearing ratio, CBR). The liquid limit, plastic limit and plasticity index were found to be A-2-7 soil according to AASHTO classification for Olokoro and A2-6 AASHTO classification for Amaoba sample. The Olokoro sample has average value of the dry density as $1.87 \mathrm{~g} / \mathrm{cm}^{3}$ and average optimum moisture content of $15.6 \%$. Whereas Amaoba has average maximum dry density of $1.88 \mathrm{~g} / \mathrm{cm}^{3}$ and average optimum moisture content of $16.1 \%$. Both soils were found to have the same average specific gravity of 2.6 having liquid limit of $44 \%$ and $40 \%$ for Olokoro and Amaoba with plastic limit of $30 \%$ and $18 \%$, plasticity index of $14 \%$ and $22 \%$ respectively. Based on the CBR values $20.3 \%$ and $19.67 \%$ respectively obtained from the two samples, the two lateritic soil will require modifications to help improve their properties for use as sub base and base materials. However, both of the soil samples are good fill materials in road work constructions.
\end{abstract}

Keywords: Laterite, pavement, compaction, optimum moisture content, materials.

\section{INTRODUCTION}

Laterite is a civil engineering material denoting a soil type that occurs in the tropics and sub-tropics. They are highly weathered soil which contains large, though extremely variable, proportion of iron and aluminum oxide as well as quartz and other minerals. Terzaghi, based on this distinction, defined soil as natural aggregate of mineral grains, which can be separated by such gentle mechanical means as agitation in water [1].

The colour varies from dark through red-brown violet or black depending largely on the concentration of iron oxide. Practically, all soils are products of the disintegration of the rocks of the earth crust. This disintegration or weathering has been brought about by the action of chemical and mechanical forces that have been exerted on the parent rock formations for countless ages.

\footnotetext{
* Corresponding author, tel: $+234-806-435-0200$
}

Nearly all laterites are of rusty-red coloration, because of high traces of iron content. They develop by intensive and prolonged weathering of the underlying parent rock. Tropical weathering (laterization) is a prolonged process of chemical weathering, which produces a wide variety in the thickness, grade, chemistry and ore mineralogy of the resulting soils. Majority of the land area containing laterites is between the tropics of Cancer and Capricorn. Typical laterite is porous and claylike. It contains the iron oxide minerals goethite, $\mathrm{HFeO}_{2}$; lepidocrocite, $\mathrm{FeO}(\mathrm{OH})$; and hematite, $\mathrm{Fe}_{2} \mathrm{O}_{3}$. It also contains titanium oxides and hydrated oxides of aluminum, the most common and abundant of which is gibbsite, $\mathrm{Al}_{2} \mathrm{O}_{3} \cdot 3 \mathrm{H}_{2} \mathrm{O}$.

According to Adewoye, et. al [2], in the construction industry, there is need for soil materials in the construction of pavements and buildings. For road construction, when a section is to be filled with soils, 
the materials are either obtained from cut-section along the road or a borrow site where the suitable materials are present. This is done especially if the materials from the road do not meet the required standards. These costs in terms of finance, resources and time are minimized. This could however, be avoided by simply improving the characteristics of the road materials that was earlier rejected.

Most soils are very suitable for use as building and pavement construction though in various cases, the addition or removal of certain constituents is required to improve their quality [2]. As the world population density increases, there is the need for the provision and maintenance of more civil engineering structures for the efficient use by the populace. However, the contemporary environment is provided with limited available materials, which may be inadequate to satisfy the construction of more structures. Hence, civil engineers are faced with the challenges of improving the quality of the existing materials to satisfy the requirement of the construction works.

Pavement is defined as a stable pucker surface constructed over the natural soil, for the purpose of supporting and distributing the wheel loads and to provide a bearing surface, capable of withstanding the wear and tear caused by the impact of the traffic [3].

Sub-grade is simply the basic foundation layer of the structure, which must eventually support all the loads that come on the pavement. The use of earthen material at sub grade level in pavement construction can never be over emphasized, as it forms the basement foundation structure, and also provide supportive strength for the rest of the overlying pavement layers. The overall performance of pavement largely depends upon the characteristics of the sub-grade. The sub-grade must have the desirable qualities such as strength, drainage, ease of compaction, and permanency of strength [3].

Most lateritic soil is encountered in an already hardened state. When the earth is exposed to air by lowering the ground water table, irreversible hardening occurs, producing a material suitable for use as road stone. The lateritic soils behave more like fine grained sands, gravel and soft rocks. It has a porous appearance which maybe self-hardening when exposed to drying. The behaviour of lateritic soils in pavements structure as stated earlier has been found to depend mainly on their particle size characteristics, the nature and strength of the gravel particles, the degree to which the soils have been compacted, as well as the traffic and environmental conditions [4].

The knowledge of the engineering properties of soils play a significant role in civil engineering construction works particularly in road constructions, foundations embankments and dams to mention a few. This made imperative, the testing of soil, on which a foundation or superstructure is to be laid. Hence, geotechnical testing of the soil material will help to know the characteristic properties of the material and its suitability for pavement and structural construction. In recent times, the alarming rates at which lives are being lost due to collapsed buildings and road failures calls for a solution. The solution could be brought by critical geotechnical testing of the engineering soils [5].

Many researchers have proposed different methods to know the suitability of different lateritic soils found within their environs and if stabilized will still affect its engineering properties [6].

Literature review on the suitability of earth in pavement construction revealed that there is a growing interest in suitable earth materials development with respects to an energy conscious and ecological design which fulfills all strength and serviceability requirement for thermal transmittance [6]. Earth as pavement construction materials has been used globally for thousands of years by various civilizations. Many different techniques have being developed, though the methods used may vary according to the local climatic conditions and environmental factors like temperature, humidity, snows and glaciations [7].

Meanwhile, as a modest estimate, it is though that as many as $30 \%$ of the world population lives in homes constructed in earth, majority of the world pavement is situated on earth as the foundation structure [8]. The idea of compacting earth to improve the quality and performance of moulded earth blocks is however, far from new and it was with wooden tamps that the first compressed earth block were produced. It is therefore pertinent to investigate the suitability of these lateritic soil to be used in road pavement and building construction materials.

The California bearing ratio (CBR) is a test to specify the mechanical strength of a soil. It is ratio between the actual pressure and the standard pressure under a constant penetration. It is usually done by a continuous load from the penetration piston. The soil tested should be under its optimum unit weight. For this reason, the proctor test is necessary to be done 
to find the optimum water content (OMC) in order to compact the soil under its optimum unit weight. This kind of continuous load does not exist in real life. The traffic load on a highway is not uniform during the time. The motion of the traffic can be described as a cyclic load on the highway. For this reason, applying the cyclic instead of the continuous load on the CBR is necessary to find its impact on the soil and to simulate the traffic surcharge on the soil [9].

The argument above therefore forms the basis for this study which is the earth or lateritic soils present at Ikwuano; precisely Amaoba, Oboro, Ikwuano Local Government Area, how good or suitable it is in pavement and civil construction works; thus comparing the geophysical properties with the Olokoro borrow-site lateritic soil to know the variability.

\section{METHODOLOGY AND DATA COLLECTION}

\subsection{The Study Area}

The lateritic soil samples used for this research were obtained from

i. Amaoba-Ime borrow site, - Ikwuano Local Government Area and;

ii. Olokoro borrow pit - Umuahia South Local Government Area.

Three samples of lateritic soils were obtained from three different locations and the samples were labeled A-C respectively. The soil samples were taken at depths of $2 \mathrm{~m}$ from the natural ground level (ngl).

\subsection{Test Procedures:}

Each of the three lateritic soils from respective borrow site were subjected to preliminary tests.

\subsubsection{Moisture content (Code of practice used: IS 2720 (Part 2).}

Clean dry moisture can with lid was weighed and recorded, the moist soil sample was placed into the moisture can and the lid replaced immediately and weighed. The lid was removed and the container with the moist soil sample was placed in the drying oven maintained at a temperature of $105^{\circ} \mathrm{C}$ for 24 hours. Immediately upon removal from the oven, the lid was replaced and the sample allowed cooling at room temperature. The moisture content, $w$, is the percentage of the dry solid mass from the equation;

$$
w=\frac{m_{2-m_{3}}}{m_{3-m_{1}}} \times 100
$$

$\mathrm{m}_{1}=$ mass of container $(\mathrm{g})$

$\mathrm{m}_{2}=$ mass of container + moist soil $(\mathrm{g})$ $\mathrm{m}_{3}=$ mass of container + dry soil $(\mathrm{g})$

The moisture condition test was developed by the Transport and Road Research Laboratory [10], which enables a rapid assessment to be made of the suitability of soils for use as fill materials.

\subsubsection{Specific gravity (Code of practice used: IS 2720 (Part 3/Sec 2).}

A known weight of oven-dried particles $W_{\mathrm{s}}$, was put into a density bottle or pycnometer and topped up with distilled water [11]. All air particles were removed from the sample. The bottle was maintained at a constant temperature $t$, dried and weighed. Calculations carried out:

Weight of density of bottle full of water at constant temperature $=\mathrm{w}_{1}$

Weight of density of bottle $+\mathrm{s}$ solid particle + water at constant temperature $\mathrm{t}=\mathrm{w}_{2}$

Submerged weight of soils $=w_{2}-w_{1}$

Specific gravity of particles $G_{s}$

$$
=\frac{\text { weight of solid particles }}{\text { weight of an equal volume of water }}
$$

But;

$$
\begin{aligned}
& \text { Weight of an equal volume of water } \\
& =\text { weight of water displaced by solids }
\end{aligned}
$$

And:

Weight of water displaced by solids $=$ weight of solids in air -

submerged weight of solids (Archimedes) $=$

$W_{s-}\left(w_{2}-w_{1}\right)$

Hence,

$$
\text { Specific Gravity } G_{s}=\frac{W_{s}}{W_{s-}\left(w_{2}-w_{1}\right)}
$$

\subsubsection{Sieve analysis: (Code of practice used: IS 2720 (Part 23).}

Oven-dried sample of soil was weighed and passed through a batch of sieves. The weight retained in each sieve was recorded, and the percentage of the total sample passing each of the sieves was calculated. The apparatus used for this test were sets of sieves which ranged from 2.00, 1.18, 0.6, 0.425, 0.15 and $0.075 \mathrm{~mm}$

The following tests were also performed:

\subsubsection{Compaction Test (Standard Proctor Test):}

A cylindrical mould $0.001 \mathrm{~m}^{3}$ in volume was filled with the soil sample in three layers, each layer was compacted by 25 blows of a standard hammer (weight $2.5 \mathrm{~kg}$, height of drop $300 \mathrm{~mm}$ each blow). 
The mould was then trimmed and weighed; hence the bulk density was recorded. The moisture content of the soil was then determined, and hence the dry density. This was repeated with soil at different moisture contents.

\subsubsection{California Bearing Ration Test: (Code of practice used: IS 2720 (Part 16)}

About $2.2 \mathrm{~kg}$ of the soil samples was pulverized enough to pass through sieve No.4. In a mixing tray, the sample was mixed with the OMC obtained from each compaction test divided into three parts. Each of the three parts was placed into the CBR mould and given 25 blows using $2.5 \mathrm{~kg}$ weight rammer. The collar was then removed and the specimen was trimmed smooth and flush with the mould. The base plate and spacer disc were removed, the mould and the compacted soil were weighed and their wet limit weight determined. The mould with compacted soil was then taken to the CBR machine and set the piston not greater than $4.5 \mathrm{~kg}$, and then the load and penetration dials set to zero. The plunger was then allowed to penetrate the sample and the load causing the penetration was recorded against the penetration. The value of the load-dial is computed:

$$
\text { Dial loads }(K N)=\text { load indicator } x \frac{P R C}{1000}
$$

Where PRC = proving ring constant which is equal to $60 K N$

The calculated load in $\mathrm{KN}$ is now used in the computation of CBRs using the following expression

$C B R$ at $2.5 \mathrm{~mm}$ penetration

$=\frac{\text { dial guage at } 2.5 \times P R C \times 100}{1370}$

CBR at $2.5 \mathrm{~mm}$ penetration

$$
=13.08 \text { (for Olokoro sample) }
$$

CBR at $2.5 \mathrm{~mm}$ penetration $=$

14.75 (for Amaoba sample)

CBR at 5.0 penetration

$=\frac{\text { dial gauge at } 5.0 \times P R C \times 100}{2055}$

CBR at 5.0 penetration $=20.31($ Amaoba sample $)$,

$$
=19.67 \text { (Olokoro sample) }
$$

\section{RESULTS AND DISCUSSION}

\subsection{Preliminary Results}

From the results of the moisture content performed on the samples, it can be shown that soil is suitable as fill materials for pavement construction. The consistency limits of the soil samples are also presented; with Amaoba soil having a lower liquid and plastic limits as compared to Olokoro soil.

\subsection{Undrained Strength}

Experimental evidence has shown that the in-situ undrained strength of saturated soils is significantly anisotropic [12], the strength being depending on the direction of the major principal stress relative to the in-situ orientation of the specimen. Thus undrained strength is not a unique parameter. Thus, Amaoba soil has a higher California Bearing Ratio than the Olokoro soil. The values of the plasticity indices indicate the cohesion (i.e. the strength) and permeability of the soil. Amaoba soil having higher value of plasticity index has higher cohesion and lower permeability.

Table 1: Some geotechnical properties of Amaoba and Olokoro lateritic soil samples

\begin{tabular}{lcc}
\hline Properties & $\begin{array}{c}\text { Amaoba } \\
\text { Sample A }\end{array}$ & $\begin{array}{c}\text { Olokoro } \\
\text { Sample B }\end{array}$ \\
\hline Moisture Content & $13.48 \%$ & $13.25 \%$ \\
Specific gravity & 2.6 & 2.6 \\
Liquid limit & $40 \%$ & $44 \%$ \\
Plastic limit & $18 \%$ & $30 \%$ \\
Plasticity Index & $22 \%$ & $14 \%$ \\
Undrained strength, & 4.23 & 5.50 \\
$\mathrm{Cu}_{\mathrm{u}\left(\mathrm{kN} / \mathrm{m}^{2}\right)}$ & & \\
Compressive index, & 4.54 & 2.95 \\
$\mathrm{C}_{\mathrm{c}}$ & & \\
California Bearing & $20.31 \%$ & $19.67 \%$ \\
$\begin{array}{l}\text { Ratio, CBR } \\
\text { Maximum Dry }\end{array}$ & 1.88 & 1.87 \\
$\begin{array}{l}\text { Density, MDD }\left(\mathrm{g} / \mathrm{cm}^{3}\right) \\
\text { Optimum Moisture }\end{array}$ & $16.1 \%$ & $15.6 \%$ \\
Content, OMC & $\mathrm{A}-2-6$ & $\mathrm{~A}-2-7$ \\
Class of Soil & & \\
\hline
\end{tabular}

\subsection{Specific Gravity}

Tables 2 and 3 show the specific gravity of the Amaoba and Olokoro soil samples respectively. This indicates the ratio of the weight of the volume of oven-dried soil to the weight of an equal volume of water. The specific gravity of the two samples is of the same value and within the range of other inorganic soils.

\subsection{Strength Test}

The California Bearing Ratio test was used to measure the strength of the sub grade soils for the Amaoba and Olokoro soils under uniform continous loading. The values of the CBR are indicated in the tables. It is shown that the average values of the CBR 
for Amaoba soil is higher than the Olokoro soil. After finishing all the experimental tests, the results of the CBR tests performed were grouped as presented in Tables 4 - 9. Two common standard loads were used for throughout the experiments. As the penetration increase, the load also increases indicating an increase in CBR value. Corrected load is recorded after four successive penetrations. This ensured that a higher degree of accuracy was achieved during the experiment.

Table 2: Specific Gravity of Amaoba Soil Sample

\begin{tabular}{lrrrrrr}
\hline Specimen Number & \multicolumn{2}{c}{ AMB 1 } & \multicolumn{2}{c}{ AMB 2 } & \multicolumn{2}{c}{ AMB 3 } \\
\hline Bottle Number & \multicolumn{1}{c}{ X1A } & \multicolumn{1}{c}{ X1B } & X2A & X2B & X3A & \multicolumn{1}{c}{ X3B } \\
\hline mass of empty clean bottle(kg), W & 0.174 & 0.174 & 0.214 & 0.471 & 0.176 & 0.214 \\
mass of sample of oven-dry soil(kg), Ws & 0.1 & 0.1 & 0.1 & 0.084 & 0.1 & 0.08 \\
mass of bottle+water(kg), W1 & 1.173 & 1.173 & 1.212 & 1.028 & 1.173 & 1.212 \\
mass of bottle+dry soil+water(kg), W2 & 1.236 & 1.234 & 1.273 & 1.08 & 1.233 & 1.262 \\
Specific Gravity, Gs & 2.5 & 2.56 & 2.56 & 2.63 & 2.5 & 2.67 \\
\hline Average specific gravity for each sample, Gs & 2.6 & \multicolumn{4}{c}{2.6} \\
\hline Specific Gravity of the study location, Gs & 2.6 & \multicolumn{4}{c}{2.6} \\
\hline
\end{tabular}

Table 3: Specific Gravity of Olokoro Soil Sample

\begin{tabular}{lccc}
\hline Specimen Number & OL B1 & OL B2 & OL B3 \\
\hline Bottle Number & X1A & X1B & X2A \\
mass of empty clean bottle(kg), $\mathrm{W}_{\mathrm{p}}$ & 0.174 & 0.2 & 0.214 \\
mass of sample of oven-dry soil(kg), Ws & 0.086 & 0.091 & 0.1 \\
mass of bottle+water(kg), W1 & 1.173 & 1.199 & 1.212 \\
mass of bottle+dry soil+water(kg), W2 & 1.226 & 1.256 & 1.274 \\
Specific Gravity, Gs & 2.61 & 2.63 & \\
Specific Gravity of the study location, Gs & 2.6 & 2.6 & 2.6 \\
\hline
\end{tabular}

Table 4: California Bearing Ratio for Amaoba Sample 1

\begin{tabular}{cccccc}
\hline Penetration $(\mathrm{mm})$ & Reading & $\begin{array}{c}\text { Load on } \\
\text { penetration }(\mathrm{kN})\end{array}$ & $\begin{array}{c}\text { Corrected } \\
\text { load(kN) }\end{array}$ & $\begin{array}{c}\text { Standard } \\
\text { load(kN) }\end{array}$ & CBR value \\
\hline 0 & 0 & 0 & & & \\
0.625 & 2.9 & 28.362 & & & \\
1.25 & 9 & 88.02 & & & \\
1.875 & 15 & 146.7 & 205.38 & & \\
2.5 & 21 & 205.38 & & & \\
3.125 & 29 & 283.62 & & & \\
3.75 & 33 & 322.74 & & & \\
4.375 & 37 & 361.86 & 410.76 & & \\
5 & 42 & 410.76 & & & \\
5.625 & 49 & 479.22 & & & \\
6.25 & 55 & 537.9 & & & \\
\hline
\end{tabular}




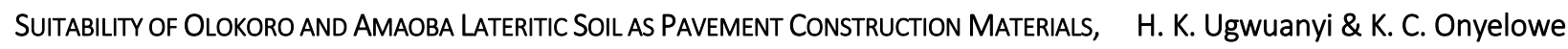

Table 5: California Bearing Ratio for Amaoba Sample 2

\begin{tabular}{cccccc}
\hline Penetration $(\mathrm{mm})$ & Reading & $\begin{array}{c}\text { Load on } \\
\text { penetration(kN) }\end{array}$ & $\begin{array}{c}\text { Corrected } \\
\text { load }(\mathrm{kN})\end{array}$ & Standard load $(\mathrm{kN})$ & CBR value \\
\hline 0 & 0 & 0 & & & \\
0.625 & 2 & 19.56 & & & \\
1.25 & 7 & 68.46 & & & \\
1.875 & 16 & 156.48 & & & \\
2.5 & 21 & 205.38 & & & \\
3.125 & 28 & 273.84 & & & \\
3.75 & 34 & 332.52 & & & \\
4.375 & 40 & 391.2 & & & \\
5 & 43 & 420.54 & 420.54 & & \\
5.625 & 48 & 469.44 & & & \\
6.25 & 59 & 577.02 & & & \\
\hline
\end{tabular}

Table 6: California Bearing Ratio for Amaoba Sample 3

\begin{tabular}{|c|c|c|c|c|c|}
\hline Penetration(mm) & Reading & $\begin{array}{c}\text { Load on } \\
\text { penetration }(k N)\end{array}$ & $\begin{array}{c}\text { Corrected } \\
\text { load }(\mathrm{kN})\end{array}$ & Standard load(kN) & CBR value \\
\hline 0 & 0 & 0 & & & \\
\hline 0.625 & 2 & 19.56 & & & \\
\hline 1.25 & 7 & 68.46 & & & \\
\hline 1.875 & 15 & 146.7 & & & \\
\hline 2.5 & 20 & 195.6 & 195.60 & 1370 & 14.28 \\
\hline 3.125 & 29 & 283.62 & & & \\
\hline 3.75 & 34 & 332.52 & & & \\
\hline 4.375 & 37 & 361.86 & & & \\
\hline 5 & 43 & 420.54 & 420.54 & 2055 & 20.46 \\
\hline 5.625 & 49 & 479.22 & & & \\
\hline 6.25 & 55 & 508.56 & & & \\
\hline \multicolumn{6}{|c|}{ Table 7: California Bearing Ratio for Olokoro Sample 1} \\
\hline Penetration(mm) & Reading & $\begin{array}{c}\text { Load on } \\
\text { penetration(kN) }\end{array}$ & $\begin{array}{c}\text { Corrected } \\
\text { load }(\mathrm{kN})\end{array}$ & Standard load(kN) & CBR value \\
\hline 0 & 0 & 0 & & & \\
\hline 0.625 & 3 & 29.34 & & & \\
\hline 1.25 & 7 & 68.46 & & & \\
\hline 1.875 & 11 & 107.58 & & & \\
\hline 2.5 & 19 & 185.82 & 185.82 & 1370 & 13.56 \\
\hline 3.125 & 27 & 264.06 & & & \\
\hline 3.75 & 34 & 332.52 & & & \\
\hline 4.375 & 39 & 381.42 & & & \\
\hline 5 & 42 & 410.76 & 410.76 & 2055 & 19.99 \\
\hline 5.625 & 51 & 478.78 & & & \\
\hline 6.25 & 59 & 577.02 & & & \\
\hline
\end{tabular}

Table 8: California Bearing Ratio for Olokoro Sample 2

\begin{tabular}{cccccc}
\hline Penetration $(\mathrm{mm})$ & Reading & $\begin{array}{c}\text { Load on } \\
\text { penetration(kN) }\end{array}$ & $\begin{array}{c}\text { Corrected } \\
\text { load(kN) }\end{array}$ & Standard load(kN) & CBR value \\
\hline 0 & 0 & 0 & & & \\
0.625 & 4 & 39.12 & & & \\
1.25 & 7.5 & 73.35 & & & \\
1.875 & 13 & 127.14 & & & \\
2.5 & 18 & 176.04 & 176.04 & & \\
3.125 & 23 & 224.94 & & \\
3.75 & 31 & 303.18 & & \\
4.375 & 37 & 361.86 & & \\
5 & 45 & 440.1 & 440.10 & & \\
5.625 & 56 & 547.68 & & & \\
6.25 & 63 & 616.14 & & & \\
\hline
\end{tabular}


Table 9: California Bearing Ratio for Olokoro Sample 3

\begin{tabular}{cccccc}
\hline Penetration $(\mathrm{mm})$ & Reading & $\begin{array}{c}\text { Load on } \\
\text { penetration(kN) }\end{array}$ & $\begin{array}{c}\text { Corrected } \\
\text { load }(\mathrm{kN})\end{array}$ & $\begin{array}{c}\text { Standard } \\
\text { load(kN) }\end{array}$ & CBR value \\
\hline 0 & 0 & 0 & & & \\
0.625 & 6.5 & 63.57 & & & \\
1.25 & 9 & 88.02 & & & \\
1.875 & 13.2 & 129.096 & & & \\
2.5 & 18 & 176.04 & 176.04 & & \\
3.125 & 24 & 234.72 & & \\
3.75 & 29 & 283.62 & & \\
4.375 & 32 & 312.96 & & & \\
5 & 37 & 361.86 & 361.86 & & \\
5.625 & 46 & 449.88 & & & \\
6.25 & 62 & 567.24 & & & \\
6.875 & 62 & 606.36 & & & \\
\hline
\end{tabular}

\subsection{Discussion of the Results}

The result from preliminary tests (particle size analysis, Atterberg's limit), as well as the engineering property tests (compaction and California Bearing Ratio (CBR) are discussed below.

Classification test: Table 1, shows the summary of results of the preliminary analysis of soil samples. The natural moisture content of the Amaoba (sample A) and Olokoro (sample B) were $13.48 \%$ and $13.25 \%$ respectively. Sample B has a lower moisture content compare to sample A. This is the function of the void ratio and specific gravities of the samples. This shows that sample $A$ and $B$ contains appreciable amount of moisture which are largely affected by the climatic conditions. The results of the Atterberg's limit tests (liquid limit (LL), plastic limit (PL) and plasticity index (PI) are shown in Table 1: The $\mathrm{LL}, \mathrm{PL}$ and $\mathrm{PI}$ of the natural soil samples are $44 \%, 30 \%, 14 \%$ respectively, for sample B and $40 \%, 18 \%, 22 \%$ respectively, for sample $A$.

According to [8], liquid limit less than $35 \%$ indicates low plasticity, between $35 \%$ and $50 \%$ indicates intermediate plasticity, between $50 \%$ and $70 \%$ highly plasticity and between $70 \%$ and $90 \%$ very high plasticity and greater than $90 \%$ extremely high plasticity. This shows that the LL of both soil samples falls between intermediate plasticity.

Some geotechnical properties test: the results are shown in Table 1, the optimum moisture content of the samples are $16.1 \%$ and $15.6 \%$ with maximum dry density of $1.88 \mathrm{~g} / \mathrm{m} 3$ and $1.87 \mathrm{~g} / \mathrm{m} 3$ for sample A and $B$ respectively.

The CBR result is summarized in the Tables 4 to 9 , having average valve of $20.3 \%$ for Amaoba sample and $19.6 \%$ for Olokoro sample. The Amaoba soil which has the lowest sand fraction presents the highest CBR increment ratio. The CBR values can be compared to the standard CBR specifications for pavement construction in table 10 .

\section{Table 10: CBR Specifications}

\begin{tabular}{ll}
\hline Standard specification for pavement constructions \\
\hline Sub-grade & CBR $\geq 5 \%$ \\
Sub-base & $C B R \geq 25 \%$ \\
Base & $C B R \geq 80 \%$ \\
\hline
\end{tabular}

\section{CONCLUSION}

After analyzing the soil samples, it was very observable that both soils meet the requirement for pavement construction. However, the characteristic strength of the soils can be modified to increase their qualities in order to achieve a higher grade of the geotechnical propertises.

From the observations of the results, sample $A$ (Amaoba lateritic soil) is found to be more suitable in pavement construction to sample B (Olokoro lateritic soil). However, both samples can be improved on their geotechnical properties.

\section{REFERENCES}

[1] Onyelowe, K. C. and Agunwamba, J. C. "Geotechnical Examination of the Geophysical Properties of Olokoro Borrow Site Latertic Soil For Road Works", Nigerian Journal of Technology (NIJOTECH) Vol. 31, No 3, November, 2012, pp. 397-400

[2] Adewoye, A. O. Adegbola, A.A., Boloji, A.A., Opebiyi, D. F. "Engineering Properties Foundational Materials of Oyo-Ohomoso Road in Southwestern Nigeria". Science focus. 9:42-47. 2004 
[3] Gark, S. K. (2011) Soil mechanics and Geotechnical Engineering, 8 ${ }^{\text {th }}$ edition. 2011

[4] Gidigasu, M. D., "Laterte soil Engineering: Pedogenesis and Engineering principles". Development in Geotechnical Engineering, 9:554. 1976

[5] Oladeji, O. S. and Raheem, A.A. "Soil tests for Road construction". Journal of Science, Engineering and Technology. 9 (2): 3971-3981. 2002

[6] Sadek, D. and Roslan, H. A. Review on Bricks and Stabilized Compressed Earth blocks, 2010.

[7] Lee, P. Y., and Suedkamp, R. J. (1972). "Characteristics Of Irregularly Shaped Compaction Curves of Soils", Highway Research Record No 381:
[8] McNally, G. H. Soil and Rock Construction Materials, Routledge, London, 1998, pp 276282.

[9] Robert Nini, "Effect of Cyclic Load on California Bearing Ratio of Soaked Clay", Proceedings of the 2nd World Congress on Civil, Structural, and Environmental Engineering (CSEE'17), Barcelona, Spain - April 2 - 4, 2017

[10] Parson, A.W., and Boden, J.B. "The moisture condition test and its potential application in earthworks". TRRL Report 522, Crowthorne, Berks. 2014

[11] Smith, M.J. "Soil Mechanics (5 $5^{\text {th }}$ Edition), Fletcher \& Son Ltd, Norway 2013

[12] Duncan, J.M, and Seed, H.B. "Strength variation along failure surfaces in clay. Journal of the ASCE, 92(sm6) 8-104, 2012. 